JOURNAL OF SECURITY AND SUSTAINABILITY ISSUES

ISSN 2029-7017 print/ISSN 2029-7025 online

2020 September Volume 10 Number 1

https://doi.org/10.9770/jssi.2020.10.1(25)

\title{
Scopus
}

\section{SYSTEM CONSTRUCTS FOR THE INVESTMENT SECURITY OF A COUNTRY}

\author{
Aleksy Kwilinski ${ }^{1 *}$, Maryna Dielini² ${ }^{2}$, Oleg Mazuryk ${ }^{3}$, Volodymyr Filippov ${ }^{4}$, Vasyl Kitseliuk ${ }^{5}$ \\ ${ }^{1 *}$ Sumy State University, 2, Rymskogo-Korsakova st., 40007, Sumy, Ukraine; \\ ${ }^{2}$ National University of Life and Environmental Sciences of Ukraine, \\ Henerala Rodimtseva Str.19, building 1, of.12, Kyiv, 03041, Ukraine; \\ ${ }^{3}$ Taras Shevchenko National University of Kyiv, 60, Vladimirskaya street, Kiev, 01033, Ukraine; \\ ${ }^{4}$ Odessa national polytechnic university, Shevchenko avenue, 1, Odessa, 65044, Ukraine; \\ ${ }^{5}$ Ivano-Frankivsk institute of Law of the National University "Odessa Law Academy», \\ Maksymovycha st., 13, Ivano-Frankivsk, 76000, Ukraine \\ E-mail: ${ }^{1 *} k o a d u e p @ g m a i l . c o m ~(C o r r e s p o n d i n g a u t h o r)$
}

Received 15 February 2020; accepted 17 August 2020; published 30 September 2020

\begin{abstract}
The article deals with the peculiarities of formation and enforcement of the national investment security in terms of distribution of investment flows and demand for investments. The global market for investment resources was analyzed and its impact on the investment needs and security of the individual countries was evaluated. At the methodical level, the interrelation and interdependence of components of national investment security were defined. Leading security indicators were identified and characterized taking into account investment risks factors. A Process model of the country's investment security system was developed considering the risks and threats from the external environment and economic issues from the internal environment. The algorithm of complex assessment of the investment security of a country, based on the identification of stages and components of use of investments at the national level, was formed. A Model for evaluating the country's individual investment security measures was developed.
\end{abstract}

Keywords: investment security, foreign direct investments, national economy, investment areas, investment complex, security indicators, national competitiveness, security of development.

Reference to this paper should be made as follows: Kwilinski, A., Dielini, M., Mazuryk, O., Filippov, V., Kitseliuk, V. 2020. System Constructs for the Investment Security of a Country, Journal of Security and Sustainability Issues 10(1), 345-358.

https://doi.org/10.9770/jssi.2020.10.1(25)

JEL Classifications: E20, F21, O40

\section{Introduction}

The development of globalization processes, the dominance of international investment relations between the countries of the world, competition increase for foreign direct investments (FDI), increase in domestic investment of priority industries of the economic complex are significantly affecting the growth of national economies, which leads to the increased attention to ensuring investment security(IS). However, today, because of political instability, economic crisis, lack of reasonable economic and financial processes, the enormous level of corruption in public relations, and, therefore, lack of proper investment climate, a number of countries in the world cannot build up internal investment and remain uncompetitive in the fight for foreign investments. In addition, the outflow of capital abroad is going on, there is an extremely irrational industrial and regional distribution of available investment resources, which preserves the imperfect structure of the national economy of the raw material type and significantly reduces its competitiveness, recording the technological backlog, increases the dependence of the domestic manufacturers from the conjuncture of the world markets, increases financing of foreign economies. At the same time, a significant part of savings is not transformed into invest- 
ments, while the channels of interindustrial and interregional capital flow remain undeveloped.

The variety of FDI forms determines the large-scale and multilateral influence that they can have on the socioeconomic development of the investment recipient countries, which makes it possible to consider FDI as one of the important reasons for economic growth. They acquire especially greater importance in the transformation period, which is characterized by profound changes in the macroeconomic conditions of the economy functioning. The inflow of foreign capital makes it easier to solve many challenges facing a capital importing country that is why attracting and effective inclusion of foreign investments into a system of drivers of economic growth is the most important strategic and tactical task for many countries. The abovementioned testifies to the extremely low level of IS and requires the faster and qualitative development of an effective system for its assurance at the national level.

\section{Literature Survey}

In the scientific literature (Dandeker, 1990; Sheehan, 2005; Khalatur, Khaminich, Budko, Dubovych and Karamushka, 2020) investment security is viewed as the absence of danger, the condition, process of an area or system, its institutions, the level of investment, the conditions of investment activity, the possibility to save, the ability of the national economic system to support a high level of self-development.

The supporters of the reproductive approach of investment security are (Wehrly and Pohl, 2016), institutional approach (Walkenhorst and Dihel, 2006), resource-functional (Globerman and Shapiro, 2002), activity (Gaddis, 2005), strategic and managerial approach (Larson and Marchick, 2006; Khan, Shaheen, Ahmad, Bakhshaliev, Tvaronavičienè, 2019; Khan, and Kabir, 2020).

At the same time, (Anderson and Marcouiller, 2002) are the supporters of the synthesis of the two conceptual approaches to the study of the IS of national economy-by identifying and leveling of the existing threats and thanks to creating a national economy structure of that has a reserve of power. In his opinion, the IS is a set of economic relations which arise regarding the quality, scales, directions and forms of investment activity, aimed at ensuring the stability, resistance and independence of the investment cycle on a national scale, formation of open and legitimate investment relations, an effective structure of ownership and diversification of sources of financing of investment activity.

Along with this, today's absence of unambiguous substantiated interpretation of the essence of the IS should be stated. So, in our viewpoint, it is wrongful to claim that the IS is a complicated, fully unexplored indicator (McCartney, Fischer, Wils, 2004), since there is no single measure for it owing to multidimensionality of this category. Instead, (Born, H., Caparini and Fluri, 2003) highlight the positive and normative aspects of the IS. The positive aspect is the combination of protection and development of the national economy. From the standpoint of security, the IS envisages overcoming certain threats and reaching the criterion level of the main socio-economic indicators. From the perspective of the development, the IS (Haugen and Haugen, 1990) means the realization of the necessary rates of economic growth. The normative aspect of the IS is considered as a combination of the condition of the economy and its state-guaranteed changes. The ultimate goal of this combination is the competitiveness of the economy, and the means of achieving it are the instruments of indicative regulation, combined with market self-regulation.

\section{Methods}

To comply with the country's IS the formation of an effective system of its provision is essential, which should solve the methodical tasks: 1) development of the investment potential, creation of a favourable investment climate; 2) formation of mechanisms for stable and sustainable investment activity in the key sectors of the economy and providing the latest with the innovation orientation; 3) achieving long-term, stable economic growth of the national economy; 4) stable accumulation of investment recourses. 
From the methodical point of view, all the relationships and dependencies, which are specific for the investment policy and investment complex, are revealed in the system of organizational-economic forms, that is, in the mechanism of providing the IS, which unites all the phases of the investment cycle into a whole unit: from the formation of conditions and sources of investment to profit receipt by the entities involved in the investment and disposal of the used equipment. As a form of economic relations, the IS mechanism of provision guarantees the unity in the system of economic interests in the investment field and the resolution of the contradictions that arise between them, and, therefore, is a way of interests reconciliation and a form of conflict resolution (Wulf, 2004).

The components of the IS provision system should include the necessary security subsystems(scientific, legalregulatory, program-targeted, organizational, accounting and auditing, informational-analytical, institutional and technological, staff and financial provision), the entities involved in the investment activity, state regulatory instruments for this activity, objects of exchange between its entities, relations between them, as well as monitoring, analysis and assessment of the level of investment security on the basis of reasonable indicators, the use of necessary adjusting measures. The provision of the IS is accompanied by the three methodical blocks: 1) by the investment activities, characterized by the opportunity itself and focus of investment processes and connected to such notions as "investment climate" and "investment potential"; 2) by the investment area, including issues of dynamics of the investment activity of different levels, balance of interests of different entities of the IS, controllability of the investment processes; 3 ) by the realization of the investments: protection of the rights of the entities of the investment area, criminalization of the investment area, corruption component, unfair competition in the investment area.

\section{Results}

Increasing attention to the IS is due to the fact that the investments are the basis of materialization of the national economic security and, consequently, the consistency of the tasks of the latter objectively requires the activation of investment processes to ensure expanded reproduction, creating the potential for positive changes in the conditions of intensification of socio-economic contradictions, threats to self-development and independence of the state. Thus, according to the estimates of the World Bank experts, on condition that there is an increase in private investment in developing countries by $1 \%$ to GDP, all the other things being equal, the average annual growth rate of the economy increases by $0.7 \%$. In addition, the significance of providing IS is determined by the need to ensure the national interests in this area (Bath, 2011).

Thus, among the national interests in the area of the IS, in particular, one should distinguish: 1) long-term: formation of investment, and, subsequently, an innovative model of development, ensuring structural readjustment of the economy; formation of a favourable investment climate; 2 ) medium-term: ensuring the controllability of the process of capital flow(taking into account the motives and tendencies of its international movement)to the high-tech sectors of the economy, combination of the investments with innovations, acceleration of the modernization of the industry on the basis of modern technologies, ensuring the qualitative structure of foreign investments, development of stock market, collective investment institutions; 3) short-term: avoiding the destruction of the banking system, loss minimization as a result of the global financial crisis, ensuring the liquidity of enterprises and banks, avoiding exclusive dependency from foreign capital through large amounts of external debt and attracting additional international loans, protecting the economy from the expansion of foreign TNCs on the unacceptable conditions for a country, compliance with the standards of investment to GDP, maintaining the innovative orientation of investments (Dixit, 2004; US Government, 2018).

But, from the abovementioned national interests in the IS ensuring, in our opinion, it is lawfully to relate only the formation of a favourable investment climate, avoiding exclusive dependency from foreign capital through large amounts of foreign debt and attracting additional international loans, protecting the economy from the expansion of foreign TNCs on unacceptable conditions for a country, compliance with the standards of investments to GDP, maintaining the innovative orientation of investments (Makedon et. al. 2019; Lakhno et. al. 2018). 
The modern state of development of the world economy is characterized by an increase in volume of the foreign investments which, in turn, exceeds the volume growth rate of world production. At such high rates the global economy has been developing since the second half of the twentieth century. The factors such as development of international division of labor, internationalization of manufacturing, scientific and technological progress, intense activity of transnational corporations at the world market, liberalization of international trade, development of trade and economic integration became determinants of the constant growth of investment volumes. From the point of view of a macroeconomic theory, such as a global financial imbalance can be characterized as an excess of national savings in one group of countries which is invested in countries of another group with a lack of national savings compared to the need for domestic investments $(\mathrm{Li}, 2018)$. These processes lead to the growth in the importance of ensuring the long-term investment security of the countries of the world.

The main reason for the current global imbalance of investment flows between the countries of the world lies in the investment strategies of developing countries which, being owners of excessive surplus funds from the sale of energy sources and consumer goods, are looking for risk-free ways of assets investment. Table1 presents two groups of countries which are currently at different poles of the global imbalance of foreign investmentsa group of donor-countries (exporters) of capital for the rest of the world and a group of recipient-countries (importers) of capital.

Table 1. Major capital exporting and importing countries in the world, 2018

(United Nations conference on trade and development: Statistics, 2019)

\begin{tabular}{|c|c|c|c|c|c|}
\hline $\begin{array}{l}\text { The main capital } \\
\text { exporting countries }\end{array}$ & $\begin{array}{c}\text { Capital export } \\
\text { volume, bn US } \\
\text { dollars }\end{array}$ & $\begin{array}{l}\text { Share in the world } \\
\text { capital export, \% }\end{array}$ & $\begin{array}{c}\text { Major capital } \\
\text { importing countries }\end{array}$ & $\begin{array}{c}\text { Volume of capital } \\
\text { import, bn US } \\
\text { dollars }\end{array}$ & $\begin{array}{l}\text { Share in the world } \\
\text { capital import, } \%\end{array}$ \\
\hline Germany & 256,0 & 18,9 & the USA & 436,0 & 35,5 \\
\hline China & 186,9 & 13,8 & Great Britain & 172,0 & 14 \\
\hline Saudi Arabia & 94,8 & 7,0 & Brazil & 97,0 & 7,9 \\
\hline the Netherlands & 79,9 & 5,9 & Turkey & 49,1 & 4,0 \\
\hline South Korea & 78,6 & 5,8 & Australia & 41,8 & 3,4 \\
\hline Taiwan & 56,9 & 4,2 & Canada & 41,8 & 3,4 \\
\hline Kuwait & 54,2 & 4,0 & France & 31,9 & 2,6 \\
\hline Singapore & 52,8 & 3,9 & Other & 560,1 & 45,6 \\
\hline Russia & 51,5 & 3,8 & \multirow{7}{*}{ Total } & \multirow{7}{*}{1228,3} & \multirow{7}{*}{100} \\
\hline Qatar & 47,4 & 3,5 & & & \\
\hline Switzerland & 43,3 & 3,2 & & & \\
\hline the UAE & 43,3 & 3,2 & & & \\
\hline Norway & 37,9 & 2,8 & & & \\
\hline Other & 172,0 & 12,7 & & & \\
\hline Total: & 1354,3 & 100 & & & \\
\hline
\end{tabular}

As the IMF experts note, there is a risk that the imbalance of foreign direct and portfolio investment flows will increase again. Indeed, the fundamental factors that caused a new turn of imbalance in the world economy (at the beginning of the 21 st century the share of portfolio investments increased again), which are connected with the structure of the world financial and monetary system, have not disappeared (Fig.1). 


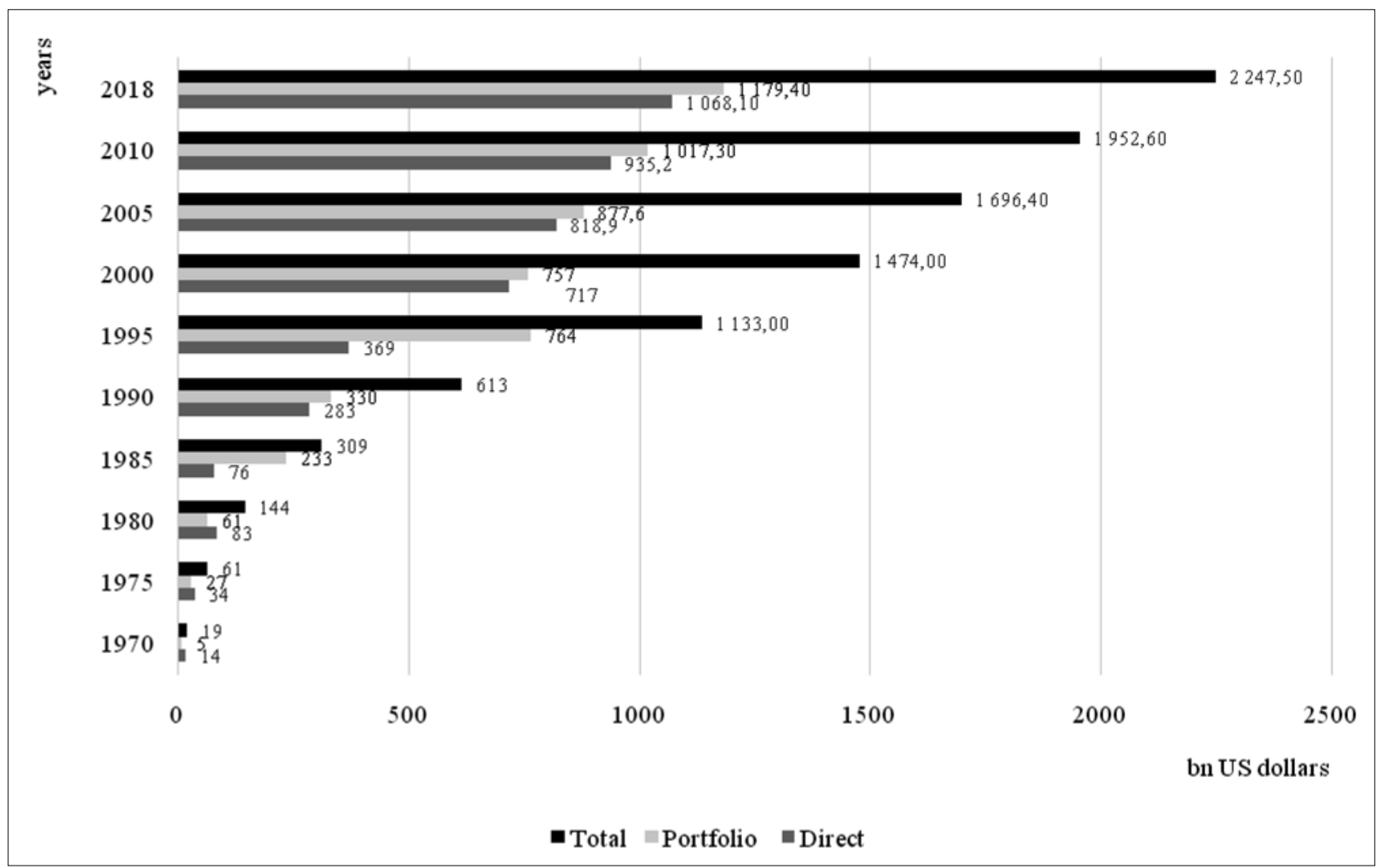

Figure 1. Direct and portfolio investment flows to the leading developed countries of the world during the period from 1970 to 2018 (Global financial stability report, 2019)

Summarizing the results of the study, it should be noted that global financial imbalances appear quite differently in the world economy both in space and in the areas of international economic relations. It was proven that at the present stage there is an activation of the imbalance of the economic system and it was confirmed that the financial and investment components largely determine the gaps in its functioning. There is a clear interconnection and interconditionality between the IS of a country and its elements (Fig. 2).

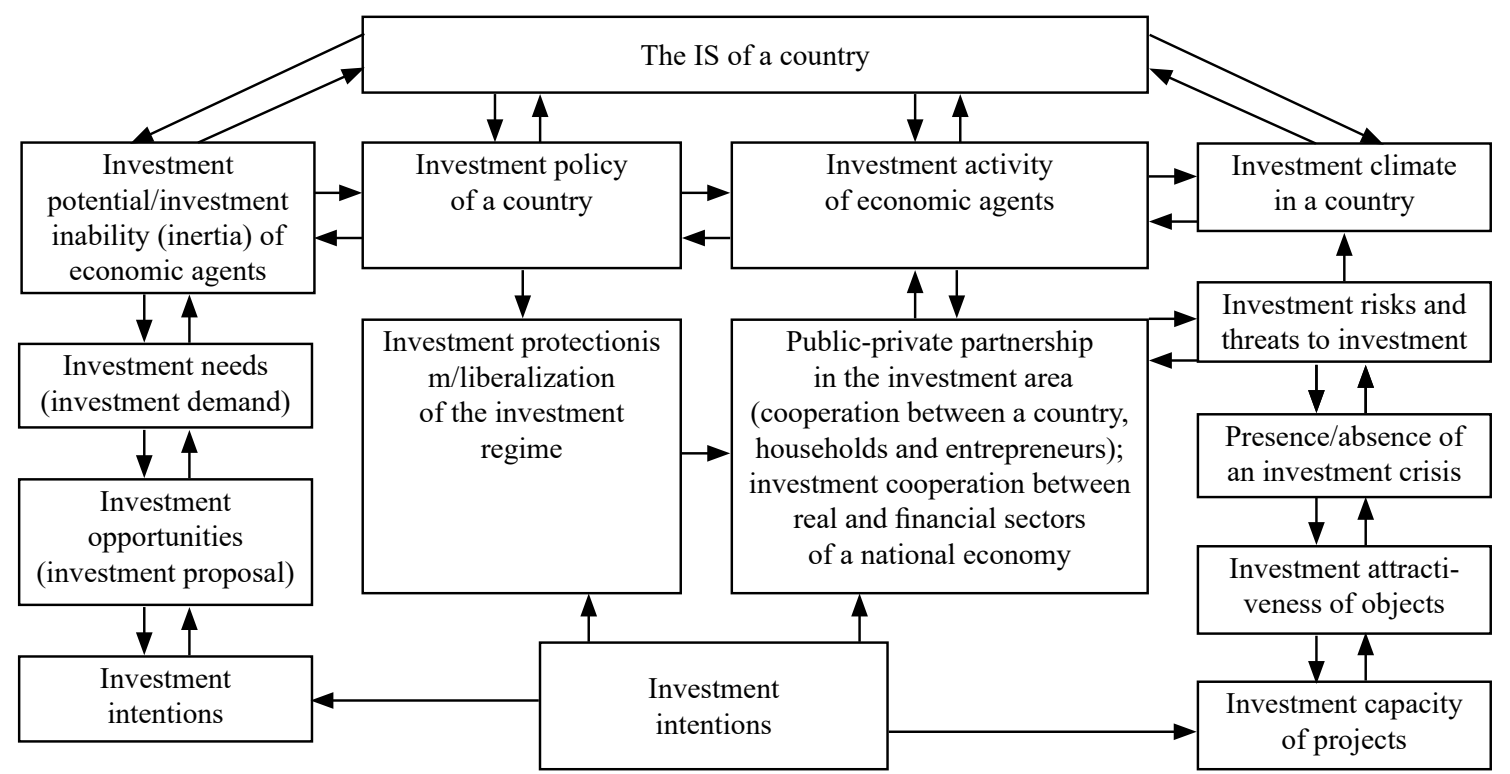

Figure 2. The interconnection and interconditionality of the elements of the country's IS 
At the same time, the lawfulness of inclusion of public-private partnership into the elements of the IS in the investment area is justified by the fact that the cooperation of a country, households and entrepreneurs, leading to increased investment activity of economic agents and, thereby, increasing the level of the IS, simultaneously, is accompanied by investment risks and investment threats, implementation of the latter causes a deterioration of the investment climate and, consequently, a decrease in the level of the IS. Based on the specificity of the country's IS as an integral component of its financial security, it is directly interrelated and interdependent with the security of money turnover, tax, customs, budget, debt, currency, inflation security of a country, the security of the banking services market, insurance and stock markets. At the same time, the degree of achievement of such components of the economic security of a country as energy, food, innovative, technological, demographic, foreign economic, as well as social, environmental and technogenic security, reduction/increase of the level of shadowing national economy, unproductive capital outflow abroad largely depends on the level of the IS of a country. Besides that, because of the need to protect investors from the unauthorized use of confidential data, which are used in management decision making, the level of information security lays an important role in providing the IS (Borger, 2015).

That is, it can be stated with confidence that the level of state's IS significantly influences the levels of consumption and accumulation, supply and demand at goods and financial markets, labor market, increase/decrease of business and investment activity of households, economic entities, industries, regions, sectors of national economy and, thus, determines the level of socio-economic development of a country in general, stimulates/ brakes economic growth.

At the same time, the authors consider competitiveness of economy as the main criterion of sufficiency of the IS. They note that an effective indicator of the IS is a characteristic of the economy which: establishes a cause and effect connection between the volume of investments and the economic security of a country; reflects longterm tendencies in the economic development of a country; is representative, sensitive and reliable as well as dynamic, which allows to determine the tendency of development of the investment component of economic security of a country.

The criteria for generalizing IS indicators can be: 1) economic activity; dynamics of production volumes; 2) intensity of investment and innovation processes; the level and quality of life of the population; 3 ) environmental condition; 4) international competitiveness of the economy (Table 2).

Table 2. Leading security indicators taking into account investment risk factors

\begin{tabular}{|c|c|c|}
\hline Criteria & Indicators & Risk factors \\
\hline \multirow{4}{*}{$\begin{array}{l}\text { Dynamics and quality } \\
\text { of economic growth- } \\
\text { the transition to an } \\
\text { innovative economy }\end{array}$} & 1) Savings share in gross investments to GDP & Macroeconomic \\
\hline & 2) Ratio of investment growth rates and GDP & Macroeconomic \\
\hline & 3) Level of renewal and modernization of fixed capital & Macroeconomic \\
\hline & FDI inflow to GDP. FDI outflow to GDP & Macroeconomic \\
\hline \multirow{4}{*}{$\begin{array}{c}\text { Strategic priorities } \\
\text { for economic growth } \\
\text { and balance of market } \\
\text { relations }\end{array}$} & 1) Sectoral priorities for investment in science absorbing industry & $\begin{array}{c}\text { Mesoeconomical } \\
\text { (sectoral and regional) }\end{array}$ \\
\hline & $\begin{array}{l}\text { 2) Regional priorities for placement and investment of economic } \\
\text { entities and development of social sphere }\end{array}$ & Mesoeconomical \\
\hline & $\begin{array}{l}\text { 3) Interregional and intersectoral priorities for development of market } \\
\text { connections }\end{array}$ & Mesoeconomical \\
\hline & 4) Transnationalization index & Mesoeconomical \\
\hline \multirow{4}{*}{$\begin{array}{l}\text { Priorities for income } \\
\text { growth(profitability) } \\
\text { and production } \\
\text { efficiency }\end{array}$} & $\begin{array}{l}\text { 1) Payback and profitability of investment projects considering } \\
\text { discounting }\end{array}$ & $\begin{array}{l}\text { Microeconomic (enterprise, } \\
\text { company, corporation) }\end{array}$ \\
\hline & 2) Contribution to GDP growth and budget efficiency & Microeconomic \\
\hline & 3) Increasing the competitiveness and knowledge-intensity of products & Corporate and microeconomic \\
\hline & 4) Index of internationalization & Corporate and microeconomic \\
\hline
\end{tabular}


Formation of the IS indicator system includes the following indices: 1) criterion type, by the value of which it is possible to make a conclusion about the IS condition; 2) which directly form the indicative parameters of the IS; 3) which indirectly shape the condition of the IS or reflect its impact on the condition of other fields. This makes it possible to determine the condition of affairs in the real sector of the economy, to assess the degree of riskiness of investment in a particular industry(region), as well as the correct formulation of the target guidelines necessary to eliminate the factors that negatively affect the IS (Antràs, Helpman, 2008). Among the indicative parameters he names: percentage of unprofitable enterprises; investment indexes in the fixed capital; number of small enterprises; the number of objects that have changed a form of ownership; share in the general volume of foreign direct investments; the number of used objects of the industrial property; number of people involved in work in the given industry; dismissal of employees. In addition, he offers to carry out the security diagnostic through: a) use of the assessment of conditions (normal, pre-crisis, and crisis) of the investment objects; b) clustering of economic activity types as objects of investment according to the criterion of conditions crisis (Drobyazko et. al. 2019a; Drobyazko et. al. 2019b).

Forming the country's IS system in its organic interconnection and interdependence with the country's debt security system, the issue of the investment attractiveness of the national debt should be given a significant place as an opportunity and desire of investors to provide loan funds to a country which scale is largely determined by the country's investment (credit) rating. According to the limit values of the criteria indicators (provision of the national economy with investment resources, the ratio of their own and attracted sources) one can judge on the overall condition of the country's IS, indicators of its specific objects-on the IS of a particular objects (investment activity, investment climate), indicators of the impact of other fields of the economy on IS-on the impact on it, let us say, from the level of welfare of the population and the state of corporate and public finances, the level of development of separate branches of the economic complex and regions of a country.

In order to improve the indicative base to determine the level of the IS of regions and branches of the national economy and, therefore, the country's IS, in our opinion, except the commonly used indicators,such indicators as the ratio of investments in the region's economy to the value of productive fixed capital assets in the region should be used; the effect in related industries(the number of employees and the income of the employed by the investment of $1 \mathrm{mln}$ USD) from investments in basic industries; ratio of state budget expenses on investments to the volume of public debt (the last indicator should be an indicator of the state's debt security at the same time); the ratio of investment expenses and losses of the population and the territory prevented by the measures of the investment program/project; the magnitude of the environmental load of the investment impact due to the implementation of the investment project; sustainability/stability/variability of investment attractiveness of an industry, sector, region, state (Blackwill and Tellis, 2015).

The country's IS assessment should be supplemented by determining the degree to which the country is provided by the means of production, a benchmark of which should be the similar indicator in economically developed countries. Among the most important indicators of success of a social investment project should be the increase/decrease in support for government actions by the population.

Monitoring as an information-analytical subsystem of continuous observation for dynamics of indicators (condition, threats, risks, effects, effectiveness), collecting and providing information of the country's IS system should be multilevel, that is to monitor the condition of investment potential, investment activity, investment attractiveness, investment climate, investment conjuncture, investment image not only at the level of a country in general, but also at the levels of separate industries, branches of national economy, regions of the country, economic entities and households. Implementing the monitoring, one should determine the correspondence of the investment process to the strategic goals of the development of economic agents, identify problems, disadvantages, unresolved issues which exist in this area. Monitoring of cross-sectoral and interregional investment activity should envisage an analysis of the dynamics of capital investment development and production of goods, products, execution of works and services delivery (Wilkinson, Acharya, 2014). 


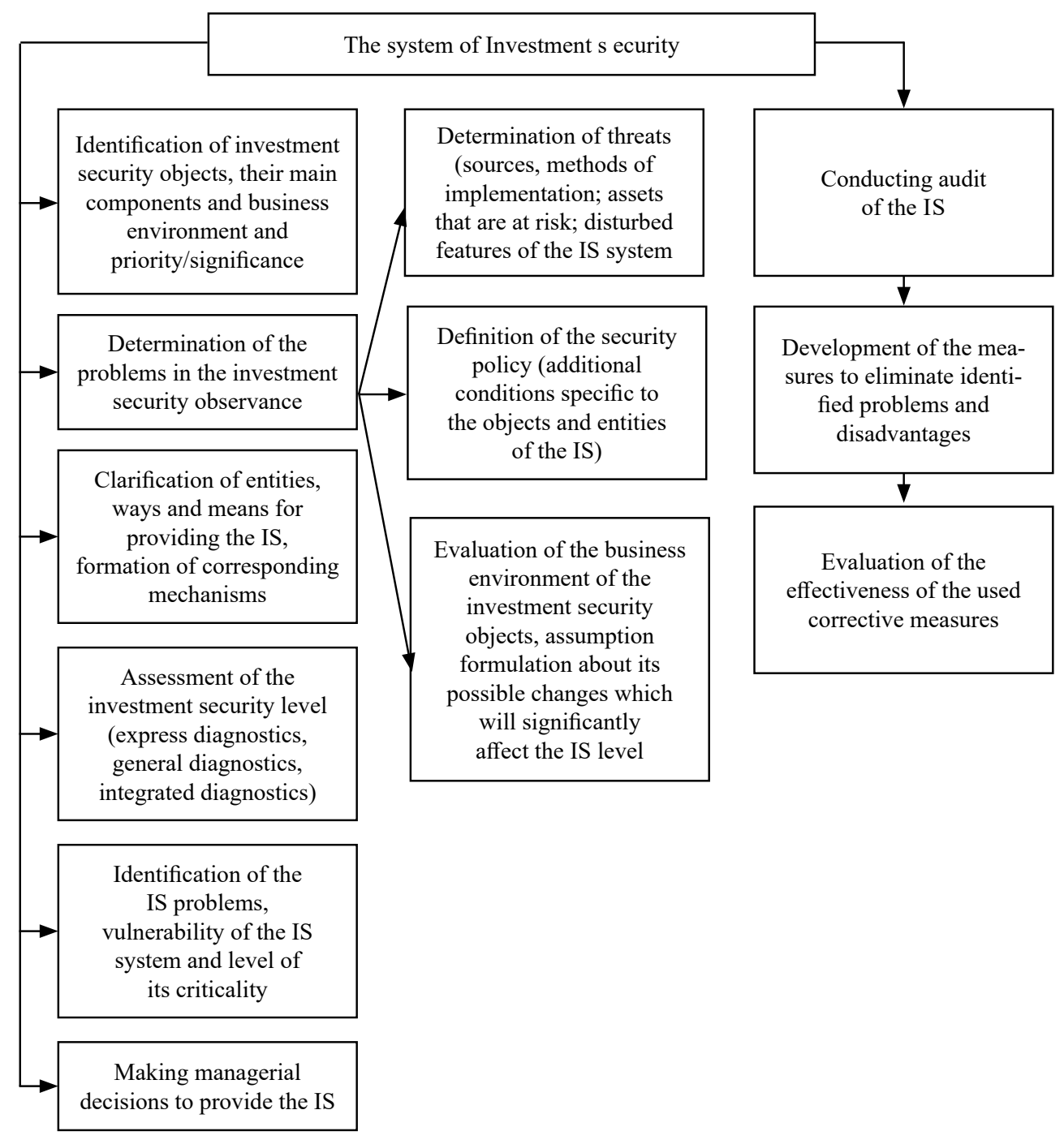

Figure 3. A process model of the country's IS system

The functional, structural, process and forming models of the country's IS system, offered by us, are, in no way, alternative. From different levels they only bring the relevant systems of state bodies, legal entities and individuals to consideration of all its parts and components for achieving the best results, raising the level of the country's IS. Among the raised properties of the IS system there may be: its integrality, availability of investment resources, their balance.

In particular, these may be the competencies of the entities providing the IS; the sequence of acquisition, processing and transfer of data and analytical materials (completeness, frequency, access to information(object and entity of access), its security, protection against unauthorized access, changes, retention of information, its personalization and authentication); requirements for automation of monitoring procedures (security of computer systems); requirements for carrying out and effectiveness of control measures; the probabilistic characteristics of the variability of the expected conditions of the flow of the investment processes and the faulty actions of the IS entities; approaches to assessing its actual/expected level (Ronis, 2011).

An important role in modeling the country's IS system, in our view, should belong to the development of a clear algorithm for integrated assessment of the IS. The author's vision of the algorithm (the order of actions of performers to solve the tasks for a finite number of actions; a system of rules for executing a discrete process which achieves the set goal in a finite period of time) of the mentioned evaluation is presented in Table 3. 
Table 3. The algorithm of the integrated assessment of the country's IS

\begin{tabular}{|c|c|}
\hline Stages & Characteristics \\
\hline The first stage & Selection of elements of the country's IS and detection of interconnection and interconditionality between them \\
\hline $\begin{array}{l}\text { The second } \\
\text { stage }\end{array}$ & $\begin{array}{l}\text { Identification of approaches(estimated, analogue(taking into account relevant parameters in economically } \\
\text { developed countries) and tools for assessment of separate elements and the IS in general }\end{array}$ \\
\hline The third stage & $\begin{array}{l}\text { Acquisition, processing and analysis of information on national, regional and corporate investment policies/ } \\
\text { strategies; macro-, meso-and microeconomic aspects of investment attractiveness, investment processes and } \\
\text { investment activity; formation and realization of investment potential at different levels of management; tendencies } \\
\text { of development of separate segments of the investment area; the investment attractiveness of economic entities, } \\
\text { industries, regions and a country in general; the investment climate in the country }\end{array}$ \\
\hline The fourth stage & $\begin{array}{l}\text { Identification of factors affecting the level of investment activity, the condition of the investment climate and the } \\
\text { country's IS; estimation of the connection density between separate variable and resulting indicators. Complex } \\
\text { review of factors of investment attractiveness of economic agents, level of concentration of investments, balance of } \\
\text { goals and interests of participants of the investment process. }\end{array}$ \\
\hline The fifth stage & $\begin{array}{l}\text { Assessment of the condition of separate elements of the country's investment security, the challenges, threats and } \\
\text { risks in this area, ability of the IS entities to counteract them/minimize their negative consequences }\end{array}$ \\
\hline The sixth stage & $\begin{array}{l}\text { Carrying out a comparative analysis of the condition of separate elements of the IS in comparison with the similar } \\
\text { indicators of foreign countries }\end{array}$ \\
\hline $\begin{array}{l}\text { The seventh } \\
\text { stage }\end{array}$ & Assessment of the condition of the country's IS in general and the formation of its security system \\
\hline The eighth stage & $\begin{array}{l}\text { Prediction of the influence of challenges, threats and risks on the state of the IS in general and its separate elements, } \\
\text { in particular }\end{array}$ \\
\hline
\end{tabular}

The given algorithm includes eight interconnected and interdependent stages of determination of the subject area of a comprehensive assessment of the Country's investment security; helps to find out the most appropriate approaches for obtaining reasonable results of approaches and tools for such assessment; stages of collecting, processing and analyzing the necessary comprehensive information needed for such evaluation; indication of factors affecting the level of components and elements of investment security; assessment of the condition of the latter, challenges, threats and risks in the investment area, as well as the challenge-, threat- and risk-tolerance of the entities of the investment security; a comparative analysis of the elements and components of investment security in current realities and in the best foreign practices; assessment of the condition of the investment security of a country for the proper formation of its security system; development of forecast scenarios of the country's investment security condition. Not less important is the assessment of the separate IS measures (Fig. 4).

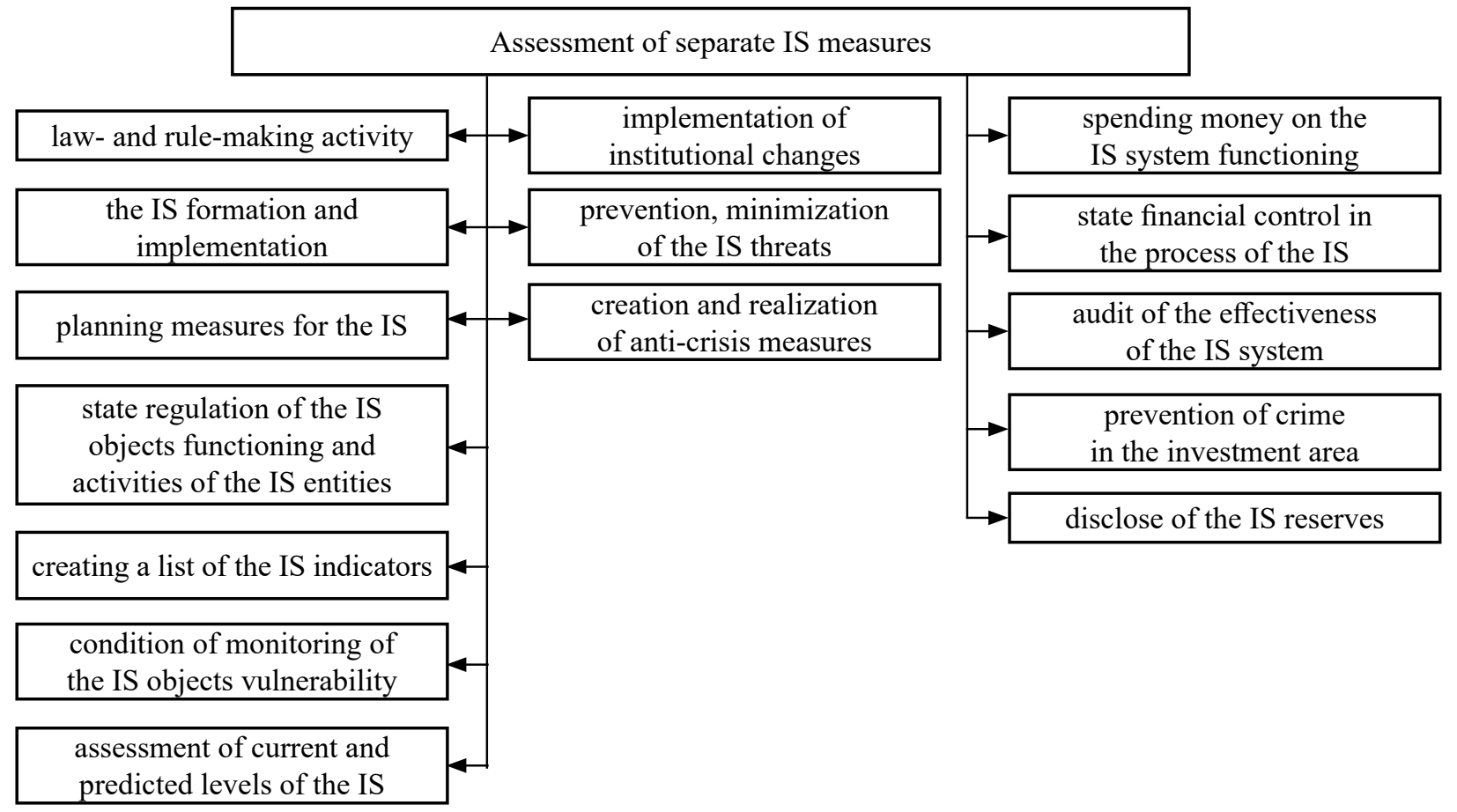

Figure 4. A model of assessment of separate measures for the country's IS 
At the same time, in order to fully implement the proposed approach to modeling the investment security system, it is necessary to promptly improve its elements and subsystem. In our opinion, the increase of the IS level of a country will be facilitated by: improvement of scientific, normative-legal and law-enforcement, program-targeted, financial, methodical, accounting-auditing, informational-analytical, institutional-technological, personnel-educational, organizational support for the investment security system formation; a clear definition of the principles of formation and implementation of the state investment policy; development of contract investment; elimination of administrative obstacles to investment activity by limiting regulatory influence of governmental bodies, debureaucratization of procedures; observance of the state guarantees of security investment and return of foreign investments due to: establishment of an insurance fund of protection of foreign investments in the country; expanding the practice of concluding intergovernmental agreements on mutual protection of investments and avoiding double taxation; development of public-private partnership in the investment area; expanding the practice of responsible investment; improving methodical approaches to the assessment of the investment climate in the country; ensuring a positive national investment image (Bieler et. al. 2004; Woo, 2004).

A clear and unambiguous perception of the effectiveness of the IS system must be necessarily based on a system of appropriate criteria of effectiveness which, in the conditions of a need to comply with economic expediency and to achieve the highest possible level of security, as well as the lack of sufficient financial resources for the formation and functioning of the given system is determined by the choice of priority funding streams of appropriate security measures (Fig. 5).

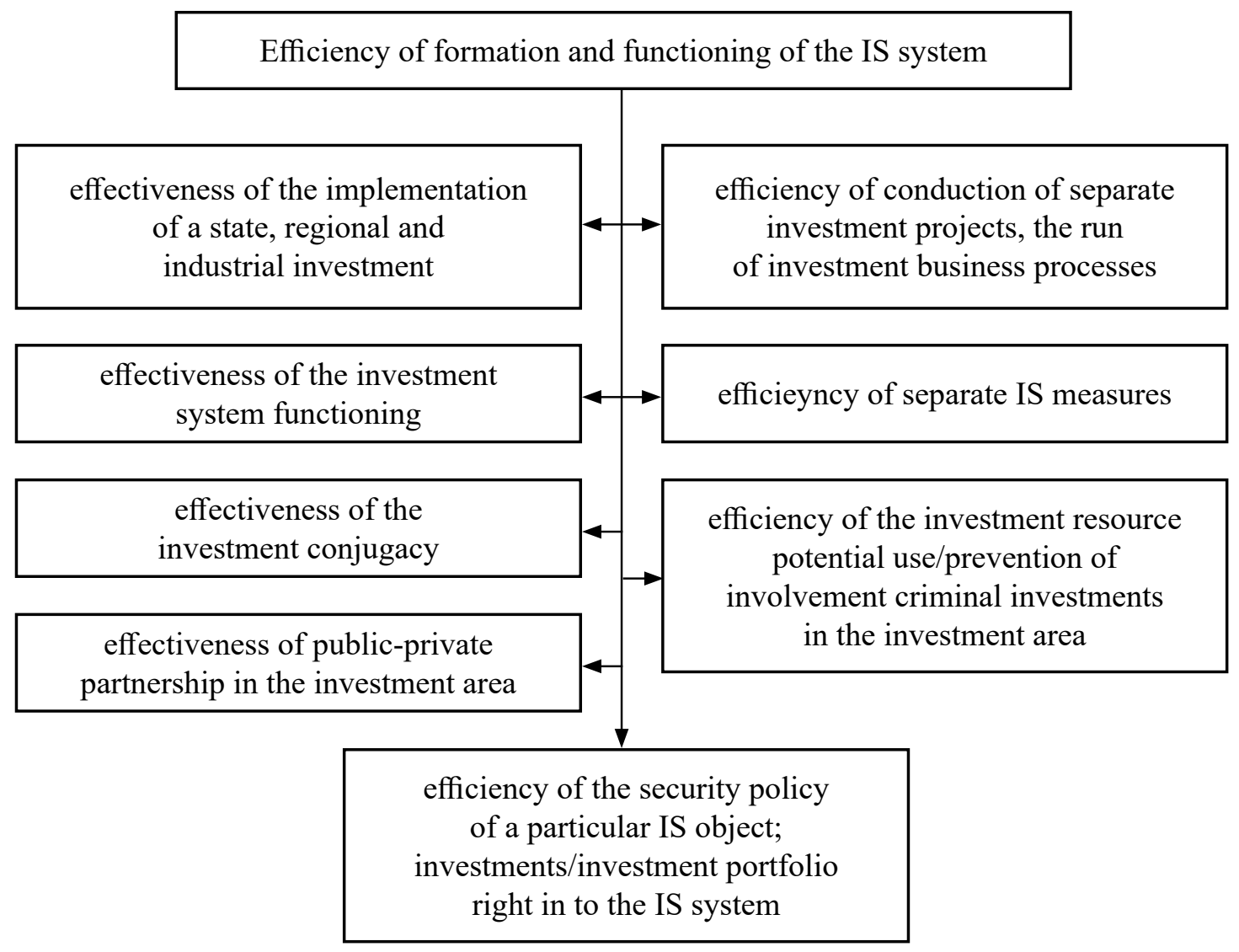

Figure 5. The components of the effectiveness assessment of the formation and functioning of the country's IS

Moreover, such criteria should allow to evaluate the possible alternatives for choosing the optimal one. And, therefore, in assessing the effectiveness of the IS system of a country, one should apply both optimality criteria and criteria for making well-grounded management decisions. In addition, the criteria should characterize both quantitative and qualitative aspects of a given system, and meet such requirements as objectivity, complexity, interpretability. 
Ability of the infrastructure and entities of the IS system, participants of investment activity in the course of implementation of a state, regional, industrial and corporate investment policy, as well as investment intentions of households to provide the growth of the investment potential, increase of investment activity and attractiveness, improvement of investment climate; formation of conditions which allow to transform the savings into investments; ensuring the multiplicative and accelerated effect of internal and external investments for the structural transformation of the national economy, maintaining financial stability in the country; increase of investments for innovative development in the country and increase of its competitiveness; absence of critical dependence of the country's economy on foreign capital; effective opposition to challenges, prevention and opposition to threats of the IS and minimization of risks in the investment area; absence/significant reduction of criminal investment level; minimization of negative consequences of investments on social sphere and environment, reduction of expenses, increase of investment income; maximizing of the IS level for a certain amount of resources on the formation and operation of this system; not exceeding the costs on providing the IS over the achieved effects from the implementation of the country's investment security system; optimization of expenses for the functioning of the country's IS system while maintaining the set level of security for a certain period; minimizing the overall expenses which consists of the expenses for the formation and operation of the country's IS system and the amount of losses in case of threats to the IS (Kikeri et. al., 2006; Tipler, 2014).

In addition, in our view, it is also appropriate to determine the efficiency criteria for separate elements and components (objects, entities, directions, security subsystems) of the country's security system. The assessment of the economic effectiveness of the country's IS strategy should be conducted on the basis of a comparison of the forecast calculations of the system of financial ratios and targeted strategic standards to their basic level. While evaluating the effectiveness of program/project investment, individual investment projects, we should take into account the whole block of the received effects among which one should differentiate the following: commercial, social, budget, environmental, management, resource; coordination of investment preferences of their participants; internal rate of return of investments indicating the presence/absence of a safety reserve of one project or another and the limit of such security. The received effects should be correlated with the corresponding expenses which will indicate the effectiveness/inefficiency of investment projects. So, for example, budget efficiency $(\mathrm{Eb})$ should be calculated as:

$$
E_{b}=\frac{\sum T}{\sum I}
$$

where $\Sigma T-$ tax revenues (as an alternative, the cost savings indicator of the state and local budgets for the implementation of the investment project can be used);

$\Sigma I-$ volume of investments in the economy of a country.

In order to increase the validity of the efficiency evaluation of the investment project together with the analysis of net present value, profitability index, payback period and internal rate of return (which all make it impossible to evaluate the probability of a risk of unprofitability of a project due to imperfect forecasting of a cash flow/discount rate, recent income accounting based on assumption of completeness of information), we should take into account the approaches based on consideration of uncertainty and risks of investment projects. In particular, it is advisable to use the calculation of the indicator of sustainability of the investment project as a relation of the difference between the risk-free rate of discount/the lower level of the discount rate(in the case of the project realization at the cost of borrowed funds-this is the maximum credit interest that an economic agent is able to repay at the cost of the future income) and the internal rate of return (the upper limit of the discount rate)to the risk-free discount rate/lower level of the discount rate. When the indicator of the investment project sustainability is one, the discount rate will correspond to the risk-free rate of discount, while when the sustainability is close to zero, it will approach the double rate, accordingly. Determination of the effectiveness of the investments/investment portfolio exactly into the IS system $\left(E_{i n v}\right)$ should be based on the calculation of the following relation: 


$$
E_{i n v}=\frac{\sum E}{\sum V_{i s}}
$$

where $\sum E-$ the total effect from the IS system functioning;

$V_{i s}$ - expenses on formation and implementation of the IS system (design; personnel; infrastructure; development of concepts, strategies, policy; state regulation; development of a system of criteria and indicative indexes and their monitoring; decision-making in the management of the IS; relieving the consequences of the threats realization; insurance, etc.)

Constant attention in assessing the effectiveness of the country's IS system should be paid to the determination of the effectiveness of the applied preventive security measures.

\section{Discussion}

The importance of substantiation of the country's IS models is determined by the fact that they have to:

1) become a guidance for determination of the requirements for the system creation and operation, its subsystems and elements, required recourses for this, means, ways, methods and tools in the security direction;

2) direction and stages of adjustment, evaluation of the efficiency and effectiveness of a system;

3) enable different levels of the IS objects protection;

4) control the condition of a system;

5) coordinate and integrate the efforts of the IS entities. The country's IS can be viewed in functional, structural, process and formative aspects. At the same time, one should keep in mind the factor aspect of such a system that is the interconnection/interdependence/ interconditionality of its element. Each aspect of the IS system formation implies the availability of its appropriate model which, from different perspective, bring the appropriate developers and all the state bodies involved in the effective functioning of such a system, legal entities and individuals to accounting all its parts and components to achieve the best results, to increase the country's IS level. A comprehensive review of the IS models should also include the characteristics of the IS policy, which is an expression of the security requirements to its security system.

\section{Conclusions}

It is determined that by the investment security of a country we should understand: achievement of synchronization of the interests of the entities of the investment relation in order to provide the extend reproduction in the country; avoidance of asymmetry of the investment processes and losses for making unreasonable investment decisions; the level of satisfaction of the investment demand by the economic entities, households, fields of the economic complex, economic sectors, regions and a state in financial and material recourses and objects of intellectual property, which is sufficient to ensure their complete functioning and gradual development; the investment attractiveness of the investment objects; the availability of investment doctrines, strategy and policy aimed at formation and efficient use of the investment potential of the participants of the investment processes, creation of investment reserves, counteraction to unproductive capital outflow, introduction of a civilized regime of divestments, provision of favourable investment climate, prevention of challenges and threats in the investment area and reduction of risks of the investment projects realization.

The effectiveness of public investment policy in the security aspect should be assessed, first of all, according to the extent of the investment climate improvement. At the same time, the effects of attracting and crowding out the investments should be analyzed. The first of them means the availability of the effect of the multiplication of foreign and domestic investments, when the inflow of foreign investments causes the attraction of domestic investments. The second effect is created in case of displacement of foreign or domestic investments by one another. The achievement of the first type of the effect indicates a favourable investment climate, and the second one shows its adversity. 


\section{References}

Anderson, J.E., Marcouiller, D. (2002). Insecurity and the pattern of trade: an empirical investigation. Review of Economics and Statistics, 84(2), 342-52.

Antràs, P., Helpman, E. (2008). Contractual frictions and global sourcing. In The Organization of Firms in a Global Economy, ed. E. Helpman, D. Marin, T. Verdier, pp. 9-54. Cambridge, MA: Harvard Univ. Press.

Bath, V. (2011). Foreign Investment, the National Interest and National Security - Foreign Direct Investment in Australia and China. Sydney Law Review, 34(1), 5-34.

Bieler, A., Higgott, R., \& Underhill, G. (2004). Non-state actors and authority in the global system. Routledge.

Blackwill, R. D., Tellis, A. (2015). Revising US Grand Strategy Toward China, New York: Council for Foreign Relations.

Borger, O. (2015). Getting the Deal Through - Foreign Investment Review 2015, London: Law Business Research Ltd.

Born, H., Caparini, M., Fluri, P. (2003). Security Sector Reform and Democracy in Transitional Societies. Baden-Baden: Nomos.

Dandeker, C. (1990). Surveillance Power and Modernity, Polity Press, Cambridge.

Dixit, A. (2004). Lawlessness and Economics. Princeton, NJ: Princeton Univ. Press.

Drobyazko S., Barwińska-Małajowicz A., Ślusarczyk B., Zavidna L., Danylovych-Kropyvnytska M. (2019a). Innovative Entrepreneurship Models in the Management System of Enterprise Competitiveness. Journal of Entrepreneurship Education, Volume 22, Issue 4, 2019. URL: https://www.abacademies.org/articles/Innovative-entrepreneurship-models-in-the-management-system-1528-2651-22-4-408.pdf

Drobyazko, S., Makedon, V., Zhuravlov, D., Buglak, Y., Stetsenko, V. (2019b). Ethical, technological and patent aspects of technology blockchain distribution. Journal of Legal, Ethical and Regulatory Issues, Volume 22, Special Issue 2, 2019: URL: https://www. abacademies.org/articles/Ethical-Technological-and-patent-aspects-of-technology-blockchain-distribution-1544-0044-22-SI-2-365.pdf

Gaddis, J. (2005). Surprise, Security, and the American Experience. Cambridge: Harvard University Press.

Global financial stability report (2019). URL: https://www.imf.org/en/Publications/GFSR/Issues/2019/10/01/global-financial-stabilityreport-october-2019

Globerman, S, Shapiro, D. (2002). Global foreign direct investment flows: the role of governance infrastructure, World Development, 30(11), 1899-1919.

Haugen, R. A., Haugen, R. A. (1990). Modern investment theory (Vol. 5). Prentice Hall.

Khalatur, S., Khaminich, S., Budko, O., Dubovych, O., Karamushka, O. (2020). Multiple system of innovation-investment decisions adoption with synergetic approach usage. Entrepreneurship and Sustainability Issues, 7(4), 2745-2763. http://doi.org/10.9770/ jesi.2020.7.4(12)

Khan, H., Shaheen, I., Ahmad, M., Bakhshaliev, E., Khan, H.U., Kabir, A. (2020). Energy infrastructure and foreign direct investment in China. Entrepreneurship and Sustainability Issues, 8(1), 233-248. http://doi.org/10.9770/jesi.2020.8.1(16)

Kikeri, S., Kenyon, T., Palmade, V. (2006). Reforming the Investment Climate: Lessons for Practitioners. Herndon, VA, USA: World Bank Publications

Lakhno, V., Malyukov, V., Bochulia, T., Hipters, Z., Kwilinski, A., Tomashevska, O. (2018). Model of managing of the procedure of mutual financial investing in information technologies and smart city systems. International Journal of Civil Engineering and Technology, 9(8), 1802-1812. Retrieved from http://www.iaeme.com/MasterAdmin/UploadFolder/IJCIET_09_08_181/IJCIET_09_08_181.pdf

Larson, A.P., Marchick, D.M. (2006). Foreign Investment and National Security. Getting the Balance Right, CSR No. 18, July 2006, Council on Foreign Relations.

Li, J. (2018). Chinese Companies and the U.S. National Security Review. In The Clash of Capitalisms?: Chinese Companies in the United States (pp. 182-214). Cambridge: Cambridge University Press. http://doi.org/10.1017/9781316661802.007

Makedon, V., Kostyshyna, T., Tuzhylkina, O., Stepanova, L., Filippov, V. (2019). Ensuring the efficiency of integration processes in the international corporate sector on the basis of strategic management. Academy of Strategic Management Journal, Volume 18, Special Issue 1, 2019: URL: https://www.abacademies.org/articles/Ensuring-the-efficiency-of-integration-processes-in-the-international-corporate-sector-on-the-basis-of-strategic-management-1939-6104-18-SI-1-452.pdf 
McCartney, C., Fischer, M., Wils, O. (2004). Security Sector Reform. Potentials and Challenges for Conflict Transformation. Berghof Handbook Dialogue No 2. Berlin: Berghof Research Center.

Ronis, Sh., (2011). Economic Security: Neglected Dimension of National Security? Center for Strategic Conferencing Institute for National Strategic Studies, National Defense University Press, Washington, D.C.

Sheehan, M. J. (2005). International security: an analytical survey. Boulder, CO: Lynne Rienner, 65-79.

Tipler, Ch.M. (2014). Defining 'National Security': Resolving Ambiguity in the CFIUS Regulations. University of Pennsylvania Journal of International Law, Volume 35:4, 1223-1284.

Tvaronavičienè, M (2019). Insights into global trends of capital flows' peculiarities: emerging leadership of China. Administratie si Management Public, (32), 6-17. http://doi.org/10.24818/amp/2019.32-01

United nations conference on trade and development: Statistics (2019). URL: http://unctadstat.unctad.org

US Government (2018). Economic report of the president, Washington, DC: US Government Publishing Office. Available from: www. gpo.gov/fdsys/pkg/ERP-2018/pdf/ERP-2018.pdf

Walkenhorst, P., Dihel, N. (2006). Trade impacts of increased border security concerns. International Trade Journal, $20(1), 1-31$.

Wehrly, F., Pohl, J. (2016). Investment Policies Related to National Security: A Survey of Country Practices - OECD: Working Papers on International Investment - Publishing, Paris.

Wilkinson, B., Acharya, K. (2014). Open for Business: Removing the Barriers to Foreign Investment, The New Zealand Initiative.

Woo, W.T. (2004). Serious inadequacies of the Washington consensus: Misunderstanding the poor by the brightest, in J. J. Teunissen and A. Akkerman (eds), Diversity in Development: Reconsidering the Washington Consensus, The Hague: Forum on Debt and Development.

Wulf, Herbert (2004). Security Sector Reform in Developing Countries, in: Clem McCartney, Martina Fischer and Oliver Wils (eds.). Security Sector Reform. Potentials and Challenges for Conflict Transformation. Berghof Handbook Dialogue No 2. Berlin: Berghof Research Center, 9-29 and 71-73.

Aleksy KWILINSKI, D. Sc. (Economics), Professor, Sumy State University

ORCID ID: orcid.org/0000-0001-6318-4001

Maryna DIELINI, Doctor of Economics, Associate Professor, National University of Life and Environmental Sciences of Ukraine ORCID ID: orcid.org/0000-0003-1016-2305

Oleg MAZURYK, Doctor of sociological sciences, Associate Professor, Taras Shevchenko National University of Kyiv

ORCID ID: orcid.org/0000-0002-4531-7023

Volodymyr FILIPPOV, Ph.D. in Economics, Associate Professor, Odessa national polytechnic university

ORCID ID: orcid.org/0000-0003-4429-7582

Vasyl KITSELIUK, Doctoral candidate of legal science, Associate Professor of the academic department of criminal process and criminology of the Ivano-Frankivsk institute of Law of the National University «Odessa Law Academy»

ORCID ID: orcid.org/0000-0003-3960-711X

Register for an ORCID ID:

https://orcid.org/register

This work is licensed under the Creative Commons Attribution International License (CC BY). http://creativecommons.org/licenses/by/4.0/ 